\title{
Antioxidant sulfur compounds: potential therapies for autism?
}

\author{
Seth Bittker
}

Correspondence: sbittker@yahoo.com

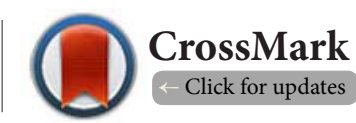

17 Edmond Street, Darien CT 06820, USA.

\begin{abstract}
Many of those with autism have biochemistry that is characterized by high levels of oxidative stress and low levels of sulfur antioxidants. Of the small set of compounds which have been shown to have some efficacy in double-blind trials in treating some aspects of autism, four are sulfur containing compounds with antioxidant properties. Specifically these four have been found to be efficacious with statistical significance in double-blind trials in autism: n-acetylcysteine, sulforaphane, l-carnitine, and a multivitamin containing methyl-sufonyl-methane and n-acetylcysteine. Each of these compounds has antioxidant properties, and there are other sulfur containing compounds with antioxidant properties which case studies suggest may have some efficacy in autism as well. The over-representation of sulfur containing antioxidants in the set of compounds that have been found to be therapeutic for autism as well as the indications of therapeutic potential of others, and the low levels of sulfur compounds and high oxidative stress that are often seen in autism biochemistry suggest that sulfur deficits are often fundamental to autism etiology, and sulfur containing antioxidants are worthy of additional study as a class of therapeutics for autism.
\end{abstract}

Keywords: Autism, NAC, sulforaphane, n-acetylcysteine, sulfate, oxidative stress, biotin, benfotiamine, DMSA, therapeutics, MSM, sulfation, biochemistry, cysteine, garlic, carnitine, TTFD, suramin, IGF-1

\section{Introduction}

With the exception of some antipsychotics which have significant side effects, there are few pharmaceuticals which have shown efficacy as treatments for the debilitating symptoms commonly associated with autism [1]. While autism is traditionally defined behaviorally, the literature suggests that many with autism have some similarities of biochemistry $[2,3]$. So compounds which may have effects on aspects of biochemistry that are commonly associated with autism would appear to be worthy of investigation as therapeutics.

\section{Hypothesis}

\section{Sulfur compounds in autism biochemistry}

Among the biochemical characteristics of autism as suggested by the medical literature are some that point to high oxidative stress. For example Adams et al., found in autism that the level of nitro-tyrosine in blood averages about $225 \%$ of controls [2], and Gonzalez-Fraguela et al., found that the level of 8-hydroxy2 deoxyguanosine (8-OHdG) in blood in autism averages about $900 \%$ of the value in controls [4]. Both of these are markers of oxidative stress.
A number of sulfur containing compounds that are crucial to sulfation or detoxification are found at lower levels in the blood in autism than controls. For example some findings in the literature for autism include: plasma free sulfate that is $35 \%$ of the level of controls, plasma total sulfate that is $72 \%$ of controls [2], total glutathione in blood that is $54 \%$ of controls [5]; cystine in blood that is $91 \%$ of controls [3]; S-adenosyl methionine in blood that is $94 \%$ of controls [2]; and lower levels of carnitine in blood relative to controls [6]. These are all sulfur containing compounds involved in detoxification or reduction of oxidative stress [7-10]. So the increased oxidative stress seen in many with autism could be related to the low levels of these sulfur antioxidants that are typically part of autism biochemistry.

One factor contributing to this sulfur deficit in autism is loss of sulfur containing compounds through the urine. For example, those with autism have on average $225 \%$ of the sulfate of controls in their urine and on average about $700 \%$ of the thiosulfate of controls in their urine [7].

There are indications that this sulfur deficit that is typical of autism may have effects on energy production, the microbiome, and behavior. While many citric acid intermediaries are 
Seth Bittker, Journal of Autism 2016,

http://www.hoajonline.com/journals/pdf/2054-992X-3-3.pdf

doi: 10.7243/2054-992X-3-3

often low in autism relative to controls, West et al., found that blood levels of succinate in autism are $111 \%$ of controls [3]. Succinate is a citric acid cycle intermediary and the enzyme responsible for metabolizing succinate requires iron-sulfur clusters as cofactors [11]. So it seems that one possible explanation for the elevation in succinate in autism and a potential contributor to dysfunction of energy production in autism is a decreased prevalence of iron-sulfur clusters in autism.

Sulfated mucins line the normal human digestive tract [12]. Wang et al., found a low relative abundance of mucolytic bacteria in the feces of those with autism relative to controls [13] and this may be related to the high comorbidity between autism and gastrointestinal disorders [14]. One explanation of these findings is that the typical sulfur deficit of autism results in decreased levels of sulfated mucins in the digestive tract which leads to the low levels of mucolytic bacteria in the microbiome and increased prevalence of gastrointestinal disease.

Elevations in blood levels of neurotransmitters and their derivatives are common in autism [15]. The primary existing pharmacologic compounds that have demonstrated efficacy in autism have been found to decrease irritability and have modes of action based on down regulating neurotransmitter receptors [16]. This suggests that excesses of neurotransmitters may be fundamental to some of the psychiatric manifestations of autism. Sulfation is the usual route for metabolism of excess neurotransmitters [17]. So it would seem that the sulfation deficit which is common in autism may be a factor in decreased capacity for metabolism of neurotransmitters in autism, which may be a factor in the irritability and other psychiatric symptoms often seen in autism.

Recently there has been an increased focus on identifying biomarkers for autism $[18,19]$. Many of the observations cited above regarding sulfur compounds in the blood or plasma in autism are highly statistically significant, and in some cases the average levels of these compounds in autism differ substantially from controls. So for example it would seem that markers such as plasma free sulfate and total glutathione would make excellent biomarkers for autism $[2,3]$ and in fact compare favorably to some other metabolic markers which have received more attention in the literature. For example, measures of serotonin in blood are some of the most widely studied biomarkers for autism. Gabriele et al., in a metaanalysis reported that elevations in serotonin in white blood cells were found in $28.3 \%$ of those with autism and elevations in serotonin in platelet rich-plasma were found in $22.5 \%$ of those with autism [19]. In contrast Adams et al., found that plasma free sulfate was below the reference range in $56 \%$ of those with autism [2]. Thus it would appear that plasma free sulfate is a more discriminatory biomarker for autism than either of these common measures of blood serotonin.

Sulfur containing antioxidants as therapeutics for autism A number of double-blind trials have been conducted in the context of autism to evaluate potential therapeutics. For many such trials the compounds tested showed little or no measureable efficacy relative to controls $[\mathbf{1 , 2 1}]$. Some compounds where double-blind trials did show statistically significant efficacy relative to control are: n-acetylcysteine where Hardan et al., found irritability decreased based on the Aberrant Behavioral Checklist ( $A B C$ ) irritability subscale [22]; sulforaphane where Singh et al., found behavior improved based on an $A B C$ and Social Responsiveness Scale measures [23]; I-carnitine where Fahmy et al., found behavior improved based on a Childhood Autism Rating Scale [24]; and a multivitamin that contained substantial amounts of methyl-sufonyl-methane and n-acetyl cysteine where Adams et al., found behavior improved based on a Parental Global Impressions measure [25]. What do these compounds have in common beyond their efficacy in autism? They are in fact all sulfur containing compounds with significant antioxidant properties [26-29]. In addition in the trials of the sulfur containing multivitamin, partial normalization in sulfur biochemistry in the blood was observed relative to controls, which would seem to confirm the relevance of this biochemistry to the multivitamin's efficacy [25].

There are related trials in the literature on autism and trials in potentially related conditions providing additional color on two of the therapies mentioned above. With respect to carnitine in autism a separate double-blind trial showed efficacy and found that improvement was correlated to levels of free carnitine [30]. With respect to $n$-acetylcysteine, Wink et al., found in a recent double-blind trial that there was no statistically significant difference in improvement in a Clinical Global Impressions index associated with $\mathrm{n}$-acetylcysteine relative to placebo. Glutathione level in blood did rise though in this trial for those receiving n-acetylcysteine [31]. Other trials have shown that $\mathrm{n}$-acetylcysteine as an adjunct to risperidone is more effective at reducing irritability than risperidone alone $[32,33]$. N-acetylcysteine has also been studied in Obsessive Compulsive Disorder (OCD) and trials in this context have found that it reduces severity of symptoms [34]. As OCD has some overlap with autism symptomatically and as three of the four trials in autism found efficacy for $n$-acetylcysteine for irritability relative to placebo or as an adjunct, these data broadly support the hypothesis that $n$-acetylcysteine does have efficacy in autism.

Additional research on other sulfur containing antioxidant compounds supports the thesis that sulfur containing antioxidants may be efficacious in autism. Specifically Adams, et al., in a complex multi-stage trial of Dimercaptosuccinic acid (DMSA) observed behavioral improvement with statistical significance based on a number of measures [35]. DMSA is a sulfur containing compound that is primarily used as a chelation agent, but also has antioxidant properties [36]. Lonsdale, et al., in a trialof suppositories containing the compound thiamine tetrahydrofurfuryl disulfide (TTFD) found improvements in behavior of eight of ten children with autism [37]. TTFD is a derivative of the B-vitamin thiamine and as such it is a sulfur 
containing compound with antioxidant properties $[38,39]$. Biotin is another B-vitamin which contains sulfur and from animal studies it can also serve as an antioxidant as well [40]. Blood levels of biotin in autism are typically low relative to controls [2]. Based on a urinary marker, a subset of children with autism in a Greek cohort were found to be deficient in biotin [41]. According to the same study, providing biotin to this subset led to improvement in the functional level of someof these children [41].

Two promising pharmaceutical therapies for autism are also sulfur containing compounds with antioxidant properties. Specifically suramin has been found to be effective in ameliorating autism-like behavior and metabolism in mice [42]. Suramin is a sulfur containing compound with significant antioxidant effects [43]. Insulin-like growth factor-1 (IGF-1) is an endocrine hormone which effects growth [44], and appears to be a promising treatment in ameliorating some aspects of Rett sydrome and Phelan-McDermid syndrome which are two genetic syndromes where those affected often exhibit autism like behavior $[45,46]$. In addition IGF-1 is a sulfur containing compound with antioxidant properties and has even been referred to as a "sulfation factor" due to its effects $[47,48]$.

So it would seem from double-blind trials and a wealth of other evidence that sulfur containing antioxidants are significantly over-represented among the compounds that have shown promise as therapeutics in autism.

\section{Discussion}

The sulfur deficit suggested by the literature on autism biochemistry and the empirical evidence in the literature that a number of sulfur containing antioxidant supplements may ameliorate autism symptoms suggest that:

1. Sulfur deficits and relatedly oxidative stress due to these deficits may be fundamental to the nature of autism in many cases.

2. Sulfur antioxidants are worthy of investigation in general in the context of autism as a class of therapeutics.

In the view of this author, some sulfur containing antioxidants that are worthy of additional investigation in autism include TTFD, benfotiamine, S-allyl cysteine, and Epsom salts. As previously noted a pilot studyof the thiamine derivative TTFD indicated that it has potential as a therapeutic for autism [37], but a double-blind trial could be conducted to establish if there is indeed efficacy. Benfotiamine, another thiamine derivative, is a sulfur containing antioxidant, and it has been found to relieve inflammation in diabetic neuropathy, which is a condition where oxidative stress is a major factor [49]. Benfotiamine has also been found to improve mood in recovering alcoholic men [50]. As autism often features oxidative stress and debilitating irritability $[2,16]$, logic suggests that benfotiamine should be evaluated for efficacy in autism. S-allyl cysteine is a sulfur containing antioxidant compound in garlic with neuroprotective effects [51]. As autism often features high oxidative stress and clearly has neurologic manifestations, S-allyl cysteine would also seem to be worthy of investigation in autism. Epsom salts are magnesium sulfate, and magnesium sulfate injections have been found to decrease lipid peroxidation in pregnant women [52] which shows that magnesium sulfate can function as an antioxidant. In addition magnesium sulfate baths have been found to raise blood levels of sulfate, and this shows that some magnesium sulfate permeates the skin under such conditions [53]. As Epsom salt baths may lower oxidative stress and may act directly on the sulfate deficit of autism, it would seem that they are also worthy of investigation in autism.

Researchers who have interest in autism biomarkers and those who have interest in autism therapeutics are likely to be rewarded by focusing their efforts on sulfur compounds as biomarkers for autism and relatedly sulfur antioxidant compounds as therapeutics for autism.

\section{Competing interests}

The author declares that he has no competing interests.

\section{Acknowledgement}

The author is grateful for the moral support of his family and the assistance of the librarians of the Darien Public Library in tracking down articles.

\section{Publication history}

Editor: Larry Jarrett Barnhill, University of North Carolina at Chapel Hill, USA.

Received: 28-Mar-2016 Final Revised: 11-May-2016

Accepted: 18-May-2016 Published: 25-May-2016

\section{References}

1. Fung LK, Mahajan R, Nozzolillo A, Bernal P, Krasner A, Jo B, Coury D, Whitaker A, Veenstra-Vanderweele J and Hardan AY. Pharmacologic Treatment of Severe Irritability and Problem Behaviors in Autism: A Systematic Review and Meta-analysis. Pediatrics. 2016; 137 Suppl 2:S124-35. | Article | PubMed

2. Adams JB, Audhya T, McDonough-Means S, Rubin RA, Quig D, Geis E, Gehn E, Loresto M, Mitchell J, Atwood S, Barnhouse S and Lee W. Nutritional and metabolic status of children with autism vs. neurotypical children, and the association with autism severity. Nutr Metab (Lond). 2011; 8:34. | Article I PubMed Abstract | PubMed FullText

3. West PR, Amaral DG, Bais P, Smith AM, Egnash LA, Ross ME, Palmer JA, Fontaine BR, Conard KR, Corbett BA, Cezar GG, Donley EL and Burrier RE. Metabolomics as a tool for discovery of biomarkers of autism spectrum disorder in the blood plasma of children. PLoS One. 2014; 9:e112445. | Article I PubMed Abstract I PubMed FullText

4. Gonzalez-Fraguela ME, Elena M and Huang MD et al. Oxidative Stress Markers in Children with Autism Spectrum Disorders. British Journal of Medicine and Medical Research. 2013; 3:307-317.

5. Al-Yafee YA, Al-Ayadhi LY, Haq SH and El-Ansary AK. Novel metabolic biomarkers related to sulfur-dependent detoxification pathways in autistic patients of Saudi Arabia. BMC Neurol. 2011; 11:139. | Article | PubMed Abstract | PubMed FullText

6. Filipek PA, Juranek J, Nguyen MT, Cummings C and Gargus JJ. Relative carnitine deficiency in autism. J Autism Dev Disord. 2004; 34:615-23. I Article I PubMed

7. Waring RH and Klovrza LV. Sulphur metabolism in autism. Journal of Nutrition \& Environmental Medicine. 2000; 10:25-32. | Article

8. Siow RC, Sato H, Leake DS, Pearson JD, Bannai S and Mann GE. Vitamin $\mathrm{C}$ protects human arterial smooth muscle cells against atherogenic 
Seth Bittker, Journal of Autism 2016,

http://www.hoajonline.com/journals/pdf/2054-992X-3-3.pdf

doi: 10.7243/2054-992X-3-3

lipoproteins: effects of antioxidant vitamins $\mathrm{C}$ and $\mathrm{E}$ on oxidized LDL-induced adaptive increases in cystine transport and glutathione. Arterioscler Thromb Vasc Biol. 1998; 18:1662-70. | Article I PubMed

9. Evans PJ, Whiteman M, Tredger JM and Halliwell B. Antioxidant properties of S-adenosyl-L-methionine: a proposed addition to organ storage fluids. Free Radic Biol Med. 1997; 23:1002-8. | Article | PubMed

10. Gulcin I. Antioxidant and antiradical activities of L-carnitine. Life Sci. 2006; 78:803-11. | Article | PubMed

11. Oexle H, Gnaiger E and Weiss G. Iron-dependent changes in cellular energy metabolism: influence on citric acid cycle and oxidative phosphorylation. Biochim Biophys Acta. 1999; 1413:99-107. | Article | PubMed

12. Harrison MJ and Packer NH. Measurement of sulfate in mucins. Methods Mol Biol. 2000; 125:211-6. | Article I PubMed

13. Wang L, Christophersen CT, Sorich MJ, Gerber JP, Angley MT and Conlon MA. Low relative abundances of the mucolytic bacterium Akkermansia muciniphila and Bifidobacterium spp. in feces of children with autism. Appl Environ Microbiol. 2011; 77:6718-21. | Article | PubMed Abstract PubMed FullText

14. McElhanon BO, McCracken C, Karpen S and Sharp WG. Gastrointestinal symptoms in autism spectrum disorder: a meta-analysis. Pediatrics. 2014; 133:872-83. | Article | PubMed

15. Martineau J, Herault J, Petit E, Guerin P, Hameury L, Perrot A, Mallet J, Sauvage D, Lelord $G$ and Muh JP. Catecholaminergic metabolism and autism. Dev Med Child Neurol. 1994; 36:688-97. | Article I PubMed

16. Accordino RE, Kidd C, Politte LC, Henry CA and McDougle CJ. Psychopharmacological interventions in autism spectrum disorder. Expert Opin Pharmacother. 2016; 17:937-52. | Article | PubMed

17. Roth JA. Sulfoconjugation: role in neurotransmitter and secretory protein activity. Trends in Pharmacological Sciences. 1986; 7: 404-407.

18. Loth E, Spooren W, Ham LM, Isaac MB, Auriche-Benichou C, Banaschewski T, Baron-Cohen S, Broich K, Bolte S, Bourgeron T, Charman $\mathrm{T}$, Collier $\mathrm{D}$ and de Andres-Trelles $\mathrm{F}$ et al. Identification and validation of biomarkers for autism spectrum disorders. Nat Rev Drug Discov. 2016; 15:70-3. | Article | PubMed

19. Chanel G, Pichon S, Conty L, Berthoz S, Chevallier C and Grezes J. Classification of autistic individuals and controls using cross-task characterization of fMRI activity. Neuroimage Clin. 2016; 10:78-88. I Article | PubMed Abstract | PubMed FullText

20. Gabriele S, Sacco R and Persico AM. Blood serotonin levels in autism spectrum disorder: a systematic review and meta-analysis. Eur Neuropsychopharmacol. 2014; 24:919-29. | Article | PubMed

21. Levy SE and Hyman SL. Complementary and alternative medicine treatments for children with autism spectrum disorders. Child Adolesc Psychiatr Clin N Am. 2015; 24:117-43. | Article | PubMed

22. Hardan AY, Fung LK, Libove RA, Obukhanych TV, Nair S, Herzenberg LA, Frazier TW and Tirouvanziam R. A randomized controlled pilot trial of oral N-acetylcysteine in children with autism. Biol Psychiatry. 2012; 71:956-61. | Article | PubMed

23. Singh K, Connors SL, Macklin EA, Smith KD, Fahey JW, Talalay P and Zimmerman AW. Sulforaphane treatment of autism spectrum disorder (ASD). Proc Natl Acad Sci U S A. 2014; 111:15550-5. | Article I PubMed Abstract | PubMed FullText

24. Fahmy SF, El-hamamsy MH, Zaki OK and Badary OA. L-Carnitine Supplementation Improves the Behavioral Symptoms in Autistic Children. Research in Autism Spectrum Disorders. 2013; 7:159-166. I Article

25. Adams JB, Audhya T, McDonough-Means S, Rubin RA, Quig D, Geis E, Gehn E, Loresto M, Mitchell J, Atwood S, Barnhouse S and Lee W. Effect of a vitamin/mineral supplement on children and adults with autism. BMC Pediatr. 2011; 11:111. | Article | PubMed Abstract | PubMed FullText

26. Ali F, Khan M, Khan SN and Riazuddin S. N-Acetyl cysteine protects diabetic mouse derived mesenchymal stem cells from hydrogenperoxide-induced injury: A novel hypothesis for autologous stem cell transplantation. J Chin Med Assoc. 2016; 79:122-9. | Article | PubMed
27. Bai Y, Wang X, Zhao S, Ma C, Cui J and Zheng Y. Sulforaphane Protects against Cardiovascular Disease via Nrf2 Activation. Oxid Med Cell Longev. 2015; 2015:407580. | Article | PubMed Abstract | PubMed FullText

28. Calo LA, Pagnin E, Davis PA, Semplicini A, Nicolai R, Calvani M and Pessina AC. Antioxidant effect of $L$-carnitine and its short chain esters: relevance for the protection from oxidative stress related cardiovascular damage. Int J Cardiol. 2006; 107:54-60. | Article | PubMed

29. Barmaki S, Bohlooli S, Khoshkhahesh F and Nakhostin-Roohi B. Effect of methylsulfonylmethane supplementation on exercise - Induced muscle damage and total antioxidant capacity. J Sports Med Phys Fitness. 2012; 52:170-4. | Article | PubMed

30. Geier DA, Kern JK, Davis G, King PG, Adams JB, Young JL and Geier MR. A prospective double-blind, randomized clinical trial of levocarnitine to treat autism spectrum disorders. Med Sci Monit. 2011; 17:PI15-23. | Article | PubMed Abstract | PubMed FullText

31. Wink LK, Adams R, Wang Z, Klaunig JE, Plawecki MH, Posey DJ, McDougle $\mathrm{CJ}$ and Erickson CA. A randomized placebo-controlled pilot study of $\mathrm{N}$-acetylcysteine in youth with autism spectrum disorder. Mol Autism. 2016; 7:26. | Article | PubMed Abstract | PubMed FullText

32. Nikoo M, Radnia H, Farokhnia M, Mohammadi MR and Akhondzadeh S. $\mathrm{N}$-acetylcysteine as an adjunctive therapy to risperidone for treatment of irritability in autism: a randomized, double-blind, placebo-controlled clinical trial of efficacy and safety. Clin Neuropharmacol. 2015; 38:11-7. | Article | PubMed

33. Ghanizadeh A and Moghimi-Sarani E. A randomized double blind placebo controlled clinical trial of $\mathrm{N}$-Acetylcysteine added to risperidone for treating autistic disorders. BMC Psychiatry. 2013; 13:196. | Article | PubMed Abstract | PubMed FullText

34. Oliver G, Dean O, Camfield D, Blair-West S, Ng C, Berk M and Sarris J. $\mathrm{N}$-acetyl cysteine in the treatment of obsessive compulsive and related disorders: a systematic review. Clin Psychopharmacol Neurosci. 2015; 13:12-24. | Article | PubMed Abstract | PubMed FullText

35. Adams JB, Baral M, Geis E, Mitchell J, Ingram J, Hensley A, Zappia I, Newmark S, Gehn E, Rubin RA, Mitchell K, Bradstreet J and El-Dahr J. Safety and efficacy of oral DMSA therapy for children with autism spectrum disorders: part B - behavioral results. BMC Clin Pharmacol. 2009; 9:17. | Article | PubMed Abstract | PubMed FullText

36. Flora SJ, Mittal M and Mehta A. Heavy metal induced oxidative stress \& its possible reversal by chelation therapy. Indian J Med Res. 2008; 128:501-23. | Article | PubMed

37. Lonsdale D, Shamberger RJ and Audhya T. Treatment of autism spectrum children with thiamine tetrahydrofurfuryl disulfide: a pilot study. Neuro Endocrinol Lett. 2002; 23:303-8. | Pdf | PubMed

38. Lonsdale D. A review of the biochemistry, metabolism and clinical benefits of thiamin(e) and its derivatives. Evid Based Complement Alternat Med. 2006; 3:49-59. | Article | PubMed Abstract | PubMed FullText

39. Lukienko PI, Mel'nichenko NG, Zverinskii IV and Zabrodskaya SV. Antioxidant properties of thiamine. Bull Exp Biol Med. 2000; 130:874-6. | Article | PubMed

40. Feng L, Zhao S, Chen G, Jiang W, Liu Y, Jiang J, Hu K, Li S and Zhou X. Antioxidant status of serum, muscle, intestine and hepatopancreas for fish fed graded levels of biotin. Fish Physiol Biochem. 2014; 40:499-510. | Article | PubMed

41. Spilioti M, Evangeliou AE, Tramma D, Theodoridou Z, Metaxas S, Michailidi E, Bonti E, Frysira H, Haidopoulou A, Asprangathou D, Tsalkidis AJ, Kardaras P, Wevers RA, Jakobs C and Gibson KM. Evidence for treatable inborn errors of metabolism in a cohort of $187 \mathrm{Greek}$ patients with autism spectrum disorder (ASD). Front Hum Neurosci. 2013; 7:858. | Article | PubMed Abstract | PubMed FullText

42. Naviaux JC, Schuchbauer MA, Li K, Wang L, Risbrough VB, Powell SB and Naviaux RK. Reversal of autism-like behaviors and metabolism in adult mice with single-dose antipurinergic therapy. Transl Psychiatry. 2014; 4:e400. | Article | PubMed Abstract | PubMed FullText

43. Alyoussef $A$. Suramin attenuated inflammation and reversed skin tissue damage in experimentally induced atopic dermatitis in mice. Inflamm 
Seth Bittker, Journal of Autism 2016,

http://www.hoajonline.com/journals/pdf/2054-992X-3-3.pdf

Allergy Drug Targets. 2015; 13:406-10. | Article | PubMed

44. Keating GM. Mecasermin. BioDrugs. 2008; 22:177-88. | PubMed

45. Pini G, Congiu L, Benincasa A, DiMarco P, Bigoni S, Dyer AH, Mortimer N, Della-Chiesa A, O'Leary S, McNamara R, Mitchell KJ, Gill M and Tropea D. Illness Severity, Social and Cognitive Ability, and EEG Analysis of Ten Patients with Rett Syndrome Treated with Mecasermin (Recombinant Human IGF-1). Autism Res Treat. 2016; 2016:5073078. | Article | PubMed Abstract | PubMed FullText

46. Kolevzon A, Bush L, Wang AT, Halpern D, Frank Y, Grodberg D, Rapaport $R$, Tavassoli T, Chaplin W, Soorya L and Buxbaum JD. A pilot controlled trial of insulin-like growth factor-1 in children with Phelan-McDermid syndrome. Mol Autism. 2014; 5:54. | Article | PubMed Abstract | PubMed FullText

47. Sadaba MC, Martin-Estal I, Puche JE and Castilla-Cortazar I. Insulinlike growth factor 1 (IGF-1) therapy: Mitochondrial dysfunction and diseases. Biochim Biophys Acta. 2016; 1862:1267-78. | Article | PubMed

48. Moriyama S, Ayson FG and Kawauchi H. Growth regulation by insulinlike growth factor-I in fish. Biosci Biotechnol Biochem. 2000; 64:1553-62. | Article | PubMed

49. Balakumar P, Rohilla A, Krishan P, Solairaj P and Thangathirupathi A. The multifaceted therapeutic potential of benfotiamine. Pharmacol Res. 2010; 61:482-8. | Article | PubMed

50. Manzardo AM, Pendleton T, Poje A, Penick EC and Butler MG. Change in psychiatric symptomatology after benfotiamine treatment in males is related to lifetime alcoholism severity. Drug Alcohol Depend. 2015; 152:257-63. | Article | PubMed

51. Colin-Gonzalez AL, Ali SF, Tunez I and Santamaria A. On the antioxidant, neuroprotective and anti-inflammatory properties of S-allyl cysteine: An update. Neurochem Int. 2015; 89:83-91. | Article | PubMed

52. Ariza AC, Bobadilla N, Fernandez C, Munoz-Fuentes RM, Larrea F and Halhali A. Effects of magnesium sulfate on lipid peroxidation and blood pressure regulators in preeclampsia. Clin Biochem. 2005; 38:128-33. Article I PubMed

53. Mitchell SC and Waring RH. Sulphate absorption across biological membranes. Xenobiotica. 2016; 46:184-91. | Article | PubMed

\section{Citation:}

Bittker S. Antioxidant sulfur compounds: potential

therapies for autism? J Autism. 2016; 3:3.

http://dx.doi.org/10.7243/2054-992X-3-3 